\title{
Mandingueiros negros no mundo atlântico moderno
}

Resumo: 0 presente artigo visa analisar uma importante dimensão no contexto dos vínculos globais do mundo moderno: a circulação de crenças e práticas mágico-religiosas promovidas por africanos e afrodescendentes, fossem estes escravos ou livres, da África, Portugal e o Brasil. Do conjunto dessas crenças, privilegiamos o uso de amuletos protetores, ou sacos de mandinga, para demonstrar o alcance dessa circulação. A documentação que usamos na pesquisa são os processos sofridos por africanos e afrodescendentes acusados de feitiçaria e pacto demoníaco por parte do tribunal inquisitorial português.

Palavras-chave: inquisição, africanos, amuletos.

\section{"Mandingueiros" negros en el mundo atlántico moderno}

Resumen: En este artículo se pretende analizar una dimensión importante en el contexto de las relaciones globales del mundo moderno: el movimiento de las creencias y prácticas mágico-religiosas promovidas por africanos y afrodescendientes, sean esclavos o libres, de África, Portugal y Brasil. Del conjunto de estas creencias, privilegiamos el uso de amuletos protectores, o bolsas de mandinga, para demostrar el alcance de esta circulación. La documentación que utilizamos en la investigación son los procesos que sufren los africanos y los descendientes de africanos acusados de brujería y pactos demoníacos por el tribunal inquisitorial portugués.

Palabras clave: inquisición, africanos, amuletos.

\section{Black "mandingueiros" in the modern Atlantic world}

Abstract: This article analyzes a central aspect of global relations in the modern world: the circulation of magical-religious beliefs and practices promoted by Africans and Afro-descendants, whether enslaved or free, between Africa, Portugal and Brazil. Starting from a wide range of practices, we focus on the use of protective amulets, or mandinga bags to illustrate the scope of this circulation. The main source of our research is documentation derived from judicial proceedings involving the prosecution of Africans and Afro-descendants accused of witchcraft and demonic pact by the Portuguese inquisitorial court.

Keywords: inquisition, africans, amulets.

Cómo citar este artículo: Daniela Buono Calainho, "Mandingueiros negros no mundo atlântico moderno", Trashumante. Revista Americana de Historia Social 16 [2020]: 10-32.

DOI: 10.17533/udea.trahs.n16a02

Fecha de recepción: 29 de junio de 2019

Fecha de aprobación: 2 de abril de 2020

Daniela Buono Calainho: Doctora en Historia por la Universidade Federal Fluminense. Profesora Asociada de la Universidade do Estado do Rio de Janeiro.

Correo electrónico: calainho@gmail.com 


\title{
Mandingueiros negros no mundo atlântico moderno
}

\author{
Daniela Buono Calainho
}

0 estudo das trocas culturais no mundo moderno ganhou dimensões significativas com o desvendamento de um espaço que fez toda a diferença a partir do século XV: o oceano Atlântico. O protagonismo do mar Mediterrâneo na Antiguidade, tão bem estudado por Fernand Braudel, ficara para trás nesses novos tempos, em que uma nova porção do globo se descortinava aos olhos dos europeus. ${ }^{1}$ A aventura marítima a que se lançaram os portugueses, navegando ao longo do século XV pela costa ocidental africana, teve momento singular em 1488, com a passagem de Bartolomeu Dias pelo Cabo das Tormentas, no extremo sul africano. Ultrapassada a fronteira para a chegada por mar ao Oriente, o mundo conhecido se alargava cada vez mais diante das novas possibilidades de comércio e enriquecimento. A descoberta da América em 1492, e o subsequente contato com as populações nativas, fosse ali, no continente africano ou nas possessões orientais, impactou de modo indelével a história europeia e a história destas regiões recém conhecidas. $\mathrm{O}$ espaço atlântico foi palco de novos circuitos e redes comerciais, de grandes migrações populacionais e de novos rearranjos político-administrativos para dar conta de impérios coloniais que estavam se gestando. ${ }^{2}$

Este "mundo em movimento", como bem definiu A. J. R. Russell-Wood, foi alvo de reflexão por parte de uma historiografia que se propôs a pensar estes contatos. ${ }^{3}$ Desde pelo menos fins do século XIX, uns poucos trabalhos já se dedicavam a estudar o Atlântico, mas sobretudo após a Segunda Guerra Mundial, em meio aos conflitos ideológicos da Guerra Fria, um grupo de historiadores analisou o Atlântico Norte a partir de "civilizações" articuladas à Europa, que compartilhavam os mesmos valores democráticos e liberais. No caso da França, vale citar a obra de

1. Fernand Braudel, O Mediterrâneo e o mundo mediterrânico na época de Filipe II (Lisboa: Publicações Dom Quixote, 1983).

2. Para a história da expansão marítima européia, ver Luís Filipe F. R. Thomaz, De Ceuta a Timor (Lisboa: Difel, 1994); Francisco Bethencourt e Kirti Chaudhuri, dirs., História da expansão portuguesa, vols. 1-3 (Lisboa: Círculo de Leitores, 1998).

3. A. J. R. Russell-Wood, Um mundo em movimento: os portugueses na África, Ásia e América (1415-1808) (Algés: Difel, 1998). 
Jacques Godechot que desde 1947, com seu Histoire de l'Atlantique, ${ }^{4}$ abriu caminho para o estudo do Atlântico em perspectiva similar à de Fernand Braudel, expert no papel do Mediterrâneo no reinado de Filipe II na segunda metade do século XVI. ${ }^{5}$ É verdade que a obra-prima de Braudel, O Mediterrâneo e o mundo mediterrânico na época de Filipe II, só foi publicada em 1949, mas já era bem conhecida, em forma de tese, no meio historiográfico francês antes de ser impressa em Paris. Escrita, como rascunho, em um campo alemão de prisioneiros franceses durante a Segunda Guerra Mundial, foi obra orientada à distância, por ninguém menos do que Lucien Febvre.

Braudel à parte, Godechot ficou mais conhecido com seu livro Les Révolutions du Monde Atlantique, também no pós-guerra, com destaque para o nexo entre a Revolução Francesa e a independência dos Estados Unidos. Dois grandes discípulos de Braudel, por sua vez, mergulharam no Atlântico, publicando obras capitais: Frédéric Mauro, com seu Le Portugal et l'Atlantique (1960) e Pierre Chaunu, Séville et l'Atlantique, em doze volumes (1959). ${ }^{6}$ Os historiadores franceses perceberam a importância do Atlântico Sul na historiografia europeia e mundial. Entre os historiadores de língua inglesa, o britânico Charles R. Boxer, até então dedicado à história portuguesa no Oriente, publicou, em 1952, Salvador de Sá e a luta pelo Brasil e Angola, 1602-1686, inaugurando estudos dedicados a pensar a América portuguesa numa perspectiva integrada ao mundo do Atlântico sul. ${ }^{7}$

Mas o interesse pelo Atlântico Sul só se consolidou com mais força nos anos 1990 enquanto um campo diferenciado na História. História Atlântica seria a categoria de análise destinada a organizar o estudo das grandes transformações econômicas, políticas, sociais e culturais inauguradas pelos contatos entre as sociedades ao redor deste oceano. As conexões entre as Américas, a África e a Europa, tema de seminários e grupos de estudos, iniciados em Harvard ainda nos anos 1980 e depois também desenvolvidos em outras instituições acadêmicas, acabaram por gerar uma historiografia com trabalhos marcantes, a exemplo de Bernand Bailyn, Philip D. Curtin, John Elliot e Jack Greene. ${ }^{8}$ Nas palavras de Bailyn, no mundo moderno, "a

4. Jacques Godechot, Histoire de l'Atlantique (Paris: Bordas, 1947).

5. "O que é o Mediterrâneo? Mil coisas ao mesmo tempo. Não uma paisagem, mas inúmeras paisagens. Não um mar, mas uma sucessão de mares. Não uma civilização, mas civilizações sobrepostas umas às outras.Viajar pelo Mediterrâneo é encontrar o mundo romano no Líbano, a pré-história na Sardenha, as cidades gregas na Sicília [...] Tudo porque o Mediterrâneo é uma encruzilhada muito antiga. Há milênios tudo converge em sua direção, confundindo e enriquecendo sua História: homens, animais de carga, veículos, mercadorias, navios, ideias, religiões, artes de viver". Fernand Braudel, O Espaço e a História no Mediterrâneo (São Paulo: Martins Fontes, 1988) 2.

6. Frédéric Mauro, Le Portugal et l'Atlantique au XVIIe siècle, 1570-1670 (Paris: École Pratique des Hautes Études, 1960); Pierre Chaunu, Séville et l'Atlantique (1504-1650) (Paris: Éditions de l'Institut des Hautes Études de l'Amérique Latine, 1959).

7. Charles R. Boxer, Salvador de Sá e a luta pelo Brasil e Angola, 1602-1686 (São Paulo: Editora Nacional / Editora da Universidade de São Paulo, 1973). Ver ainda Charles R. Boxer, O Império Marítimo Português, 1415-1825 (São Paulo: Companhia das Letras, 2002).

8. Bernard Bailyn, Atlantic History: Concepts and Contours (Cambridge: Harvard University Press, 
Europa Ocidental, a África ocidental e as Américas foram bastante integradas em vários aspectos para merecerem ser consideradas com uma única entidade". Sanjay Subrahmanyam, estudando a Ásia portuguesa, vislumbrou histórias conectadas entre regiões distintas que se ligavam por interesses comuns ou mesmo conflitos, contrapondo-se também a uma história eurocêntrica. ${ }^{10}$

Também nos anos 90, grande contribuição para o deslanchar da História Atlântica foi de Russell-Wood, vislumbrando o mundo moderno num constante movimento de agentes administrativos, colonizadores, escravos, comerciantes, ideias, crenças, missionários. ${ }^{11}$ Serge Gruzinski retoma com toda a força estes estudos, seguindo o caminho de Russell-Wood e ampliando a análise para uma perspectiva que ele chamou de mundialização. Os intercâmbios entre as várias partes do globo, transpondo os oceanos e fronteiras territoriais, possibilitou uma história cultural ampliada, histórias partilhadas, não mais eurocêntrica, abarcando, além do Atlântico, o mundo oriental. O destaque para o período das monarquias católicas, estruturadas pela União Ibérica, entre 1580 e 1640, ensejou um "planeta filipino”, que conectou Portugal, Espanha, as possessões orientais, africanas e americanas. Estes mundos vão se ligar através das instituições civis, eclesiásticas, das relações comerciais, do trânsito de crenças religiosas, das práticas curativas e de homens que no ir e vir de sua existência, de suas atividades econômicas, vão sacramentar essa circulação planetária. ${ }^{12}$

Que dizer sobre as cidades de Lisboa, Sevilha, Roma e Istambul pintadas num biombo japonês do século XVII, exposto no Museu da Cidade de Kobe, no Japão? ${ }^{13}$ Ou sobre o cronista mexicano Chimalpahin, registrando em 1610 no seu Diário, na sua língua natal, o assassinato do monarca francês Henrique IV? ${ }^{14}$ Os exemplos apresentados por Gruzinski são vários, e o que vamos desenvolver neste artigo relaciona-se a uma dimensão importante deste contexto de globalização moderna: a circulação de crenças e práticas mágico-religiosas promovidas pelos africanos e afrodescendentes, fossem escravos ou livres, entre África, Portugal e Brasil. Do conjunto destas crenças, privilegiamos o uso de amuletos protetores, chamados neste

2005); John Elliot, Do the Americas Have a Common History? An Address (Providence: John Carter Brown University, 1998); Philip D. Curtin, The Atlantic Slave Trade: A Census (Madison: University of Wisconsin Press, 1969); Philip D. Curtin, The Tropical Atlantic in the Age of Slave Trade (Washington: American Historical Association, 1991); Jack P. Greene e Philip D. Morgan, Atlantic History: a critical appraisal (New York: Oxford University Press, 2009).

9. Bernard Bailyn, “The Idea of Atlantic History”, Itinerario 20.1 (1996): 19-44;A.J. R. Russell-Wood, "Sulcando os mares: um historiador do império português enfrenta a 'Atlantic History", História 28.1 (2009): 20.

10. Sanjay Subrahmanyam, O Império asiático português 1500-1700. Uma História política e econômica (Linda-a-Velha: Difel, 1995).

11. Russell-Wood, Um mundo em movimento 13.

12. Serge Gruzinski, As quatro partes do mundo. História de uma mundialização (Belo Horizonte / Sao Paulo: Editora UFMG / Edusp, 2014) 45.

13. Gruzinski 62-63.

14. Gruzinski 29. 
contexto de "bolsas de mandinga", para demonstrar o alcance desta circulação atlântica. A documentação que utilizamos são as denúncias e os processos sofridos por africanos e afrodescendentes acusados de feitiçaria e pacto demoníaco pelo tribunal inquisitorial português levantadas para o doutoramento que realizamos na Universidade Federal Fluminense. ${ }^{15}$

No primeiro item a seguir, trataremos de como o Tribunal do Santo Ofício incriminou como "feitiçarias" as práticas mágico-religiosas realizadas pelos africanos e afrodescendentes, dando destaque às bolsas de mandinga, bem como sua composição e seu uso, com exemplos dos processos inquisitoriais a que estes indivíduos foram submetidos, tentando demonstrar a circulação desta prática no mundo atlântico através de um comércio envolvendo escravos no Brasil e em Portugal. Por fim, examinaremos as origens africanas destes amuletos protetores, percebendo como seu conteúdo se modificou no processo da diáspora africana ao longo dos séculos de escravidão, e ainda como seus portadores em Portugal e no Brasil tinham origens diversas.

\section{Diáspora africana, escravidão e feitiçaria}

A grande movimentação de homens nos primórdios do mundo moderno, de que fala Russell-Wood, envolveu descobridores, missionários, administradores, comerciantes, aventureiros e ainda aqueles que certamente jamais retornariam à sua terra natal: os africanos escravizados. A diáspora africana mobilizou uma quantidade sem precedentes de indivíduos das origens as mais variadas, saídos de suas comunidades e rumando em direção à Europa, mas sobretudo às Américas. Foram cerca de 12 milhões escravizados, ${ }^{16}$ que ao longo da travessia atlântica, ao tempo em que durou o tráfico, tentaram reestabelecer novas relações entre colegas de infortúnio, em regra, integrantes de grupos diversos. Depois de desembarcados nos locais onde iriam servir, continuariam num dificil processo de tentativa de adaptação ao sistema escravista. $\mathrm{O}$ conjunto das crenças e devoções destes indivíduos tentaram responder, na diáspora, a uma série de anseios e problemas cotidianos inerentes à escravidão, como o temor dos senhores; a melhoria de suas condições gerais de vida; a cura de doenças e a manutenção da saúde; a segurança física e emocional; a felicidade nos relacionamentos pessoais; o desejo de vingança e de afastar pessoas; a proteção espiritual, dentre outros.

Vários africanos escravizados, libertos e seus descendentes, tanto no Brasil como em Portugal, foram incriminados e punidos por delitos do foro do Tribunal Inquisitorial $^{17}$ — fundado em Portugal no ano de 1536 - em especial aqueles

15. Daniela Buono Calainho, Metrópole das mandingas: religiosidade negra e Inquisição portuguesa no Antigo Regime (Rio de Janeiro: Garamond, 2008).

16. Ver Transatlantic Slave Data Base em https://www.slavevoyages.org (21/06/2019).

17. O Tribunal do Santo Oficio, ressurgido em Portugal em 1536, tinha por objetivo perseguir hereges, em especial os judeus convertidos ao cristianismo, denominados de cristãos-novos, e suspeitos de continuarem praticando sua religião de origem. Mas também processou outros hereges, 
considerados pela Igreja como "feitiçarias", ou seja, práticas mágico-religiosas associadas a pactos com o Diabo, justificando assim seu caráter herético e a ação repressiva inquisitorial. ${ }^{18}$ Exemplos destas práticas foram os rituais coletivos denominados calundus, envolvendo cânticos, batuques, oferendas, fervedouros com ervas e supostas incorporações de "espíritos" que curavam.

Laura de Mello e Souza, historiadora pioneira nos estudos sobre as religiosidades populares no Brasil Colonial nos anos 80, em seu clássico O Diabo e a terra de Santa Cruz, publicado em 1986, se deparou com processos de réus acusados de integrarem os calundus, em especial o que penitenciou a Luzia Pinta, nas Minas Gerais do século XVIII. ${ }^{19}$ A discussão sobre a origem deste rito e seu caráter foi polêmica: considerada como um antepassado das mães de santo dos candomblés brasileiros, Luzia protagonizou ritual analisado pela autora como de origem bantu, porém logo redimensionado pelo antropólogo Luiz Mott, que considerou que o rito estaria bem mais próximo ao ritual xinguila de nação Angola. ${ }^{20}$ Enquanto James Sweet viu os calundus como essencialmente uma continuidade da religiosidade africana, ${ }^{21}$ Laura de Mello e Souza percebeu interações entre a religiosidade centro-africana e o cristianismo. Alexandre Marcussi deu nova dimensão à discussão, destacando o caráter terapêutico do rito, "fruto de um complexo processo de reinvenções culturais e de criação de novos sistemas de pensamento ancorados numa reflexão dos escravizados centro-africanos acerca da experiência do cativeiro. Neste sentido, apontavam muito menos para um passado africano a preservar do que para um futuro de liberdades e solidariedades a se imaginar e criar". A

como sodomitas, bígamos, mouriscos, blasfemos, luteranos, clérigos que abordavam mulheres no confessionário, indivíduos que se fingiam de funcionários do Santo Ofício, feiticeiros, dentre outros, não só no Reino, mas em todas as suas colônias no Ultramar. Para a história da Inquisição na Época Moderna, ver Francisco Bethencourt, História das Inquisições: Portugal, Espanha e Itália, séculos XV-XIX (São Paulo: Companhia das Letras, 2000); Giuseppe Marcocci e José Pedro Paiva, História da Inquisição Portuguesa, 1536-1821 (Lisboa: A Esfera dos Livros, 2013).

18. A historiografia sobre feitiçaria é bastante ampla, não cabendo aqui aprofundarmos discussão dessa natureza, porém registremos que alguns autores fazem a distinção entre feitiçaria e bruxaria, constituindo-se a primeira de práticas individuais, de fabricação de filtros amorosos, unguentos, poções, beberagens, etc., que causariam danos a outros. Já a segunda, estaria envolvido um pacto explícito com o Diabo e encontros em ritos coletivos, denominados de sabás.Ver, por exemplo, Keith Thomas, Religião e o declínio da magia: crenças populares na Inglaterra, séculos XVI e XVII (São Paulo: Companhia das Letras, 1991). Consideramos, no entanto, manifestações variadas de um mesmo fenômeno, e nas fontes inquisitoriais não encontramos, em anos de trabalho com esta documentação, uma indistinção entre os termos.

19. Laura de Mello e Souza, O diabo e a Terra de Santa Cruz: feitiçaria e religiosidade popular no Brasil colonial (São Paulo: Companhia das Letras, 1986); Laura de Mello e Souza, "Revisitando o calundu", Ensaios sobre a intolerância: Inquisição, Marranismo e Anti-Semitismo, orgs. Lina Gorenstein e Maria Luzia Tucci Carneiro (São Paulo: Associação Editorial Humanitas, 2002) 293-317.

20. Luiz Mott, “O calundu angola de Luzia Pinta: Sabará, 1739”, Revista do Instituto de Arte e Cultura 1 (1994): 73-82.

21. James H. Sweet, Recriar a África: cultura, parentesco e religião no mundo afro-português (1441-1770) (Lisboa: Edições 70, 2007). 
aflição espiritual com a perda da liberdade pela escravidão, incitou a presença nestes ritos, que acabaram, para esse autor, a ganhar um viés de cura e crítica ao sistema escravista. ${ }^{22}$

Também constaram nos registros inquisitoriais adorações e oferendas a ídolos e às almas de mortos; evocações ao Diabo para os mais variados fins; sacrifícios de animais; o uso isolado ou combinado de variados ingredientes, como ervas, excrementos corporais, bebidas, alimentos, que podiam ser ingeridos ou esfregados no corpo, ou postos em lugares como encruzilhadas, rios, igrejas, portas de casas, visando curas de doenças, induzir vontades para o bem, para o amor ou para o mal; e por fim o uso de amuletos protetores junto ao corpo, denominados de bolsas de mandinga.

O historiador português Francisco Bethencourt levantou para o século XVI o percentual de 10,3\% dos casos de feitiçaria dentre todos os penitenciados pelo Santo Ofício. ${ }^{23}$ José Pedro Paiva, em outro estudo importante sobre o tema, levantou que somente 3,6\% foram processados por feitiçaria no mundo luso-afro-brasileiro, entre os séculos XVII e XVIII, ${ }^{24}$ e destes, apenas $6,5 \%$ correspondeu a negros e mulatos, ${ }^{25}$ percentual bastante pequeno, tendo em vista às perseguições aos réus cristãos-novos, foco principal das perseguições da Inquisição ibérica. No caso dos escravos, em especial, algumas de suas práticas mágico-religiosas representaram claramente uma alternativa para se defenderem dos castigos rigorosos e maus tratos impingidos pelos senhores, sendo um meio de aliviar as tensões inerentes à escravidão, como já mencionamos. Mastigar determinada erva na crença de que ela acalmaria os humores dos senhores, ou ainda utilizar as raspas das solas de seus sapatos como material de feitiços eram costumes também observados nas denúncias e processos inquisitoriais, não só em Portugal, mas também no Brasil. Esta última prática, comum à tradição europeia, viu-se temperada pelos africanos, fosse na colônia, fosse na metrópole. Não foi à toa, portanto, que de todos os negros e mulatos processados e denunciados por feitiçaria em Portugal cerca de 48\% fossem escravos. ${ }^{26}$ Mas é importante frisar, no entanto, que a documentação que trabalhamos não mostrou haver, em muitos casos, uma intenção relacionada a uma oposição frontal ao sistema escravista, estando em jogo sobretudo a sobrevivência e a adaptação ao escravismo, muito mais do que propriamente uma resistência frontal a ele.

A pressão dos interrogatórios dos inquisidores levou a confissões de algumas práticas que forneceram pistas ao historiador para desvendar um conjunto de

22. Alexandre A. Marcussi, "Utopias centro-africanas: ressignificações da ancestralidade nos calundus da América portuguesa nos séculos XVII e XVIII”, Revista Brasileira de História 39.79 (2018): 35

23. Francisco Bethencourt, O imaginário da magia: feiticeiras, saludadores e nigromantes no século XVI (Lisboa: Centro de Estudos de História e Cultura Portuguesa, 1987) 279.

24. José Pedro Paiva, Bruxaria e superstição num país sem "caça às bruxas" (1600-1774) (Lisboa: Editorial Notícias, 1997) 208.

25. Calainho 287.

26. Calainho 277, 283. 
crenças e procedimentos mágicos, embora sob o filtro dos notários do Santo Oficio. Nas salas de audiências dos tribunais distritais de Lisboa, Évora e Coimbra os inquisidores pouco a pouco faziam emergir descrições do que era a religiosidade vivida pelos africanos e afrodescendentes. Mesmo de modo indireto, através de pequenos indícios, é possível, como diria Carlo Ginzburg, decifrar aspectos de uma determinada sociedade, de uma realidade mais profunda, tal qual fazem os médicos e detetives que, por intuição e erudição, visualizam o geral a partir de sinais particulares. ${ }^{27}$ Portanto, a narrativa acusatória vai fornecer pistas importantes sobre o universo das crenças dos africanos, atribuindo a elas influências demoníacas e transformando-os assim em feiticeiros, não raro através de confissões sob tortura.

\section{As bolsas de mandinga}

O uso de amuletos protetores, chamados também de bolsas de mandinga, foi prática comum entre os africanos escravizados, registrando-se as primeiras referências ao porte delas no Brasil em fins do século XVII. Originárias da África, como veremos adiante, foram amplamente usadas também em Portugal, tendo inúmeros registros na documentação de denúncias e processos produzida pelo Santo Ofício nos séculos XVII, mas sobretudo XVIII. A partir dos anos 80, com o deslanchar da história das mentalidades e das religiosidades populares no Brasil colonial, o estudo destes amuletos protetores ganharam grande renovação de perspectiva, e foi Laura de Mello e Souza quem primeiramente se referiu a elas em estudo mais sistemático, utilizando-se das fontes inquisitoriais. Para ela, as mandingas foram a forma mais tipicamente colonial da feitiçaria no Brasil pela sua popularidade, por ser usada por brancos e por ser a mais sincrética das práticas mágicas na colônia. ${ }^{28}$ Luiz Mott, também em artigo pioneiro, analisou quatro casos de negros portadores destes patuás na vila de Jacobina, capitania da Bahia, todos presos e condenados pela Inquisição em $1745 .{ }^{29}$

Objetivando resguardar seus portadores de perigos diversos, contendas, disputas, trazer sorte e atrair mulheres, o uso destes amuletos protetores se configurou como uma prática fundamentalmente masculina pela natureza de suas atividades. Atingiram seu ápice nas primeiras décadas do XVIII, envolvendo não apenas escravos, forros, mas também homens brancos. Para o Brasil, Laura de Mello e Souza levantou 19 referências, sendo o período de maior incidência entre os anos de 1750 e 1775, especialmente na região do Grão-Pará e Maranhão. ${ }^{30}$ Do conjunto de 818 processos contra réus penitenciados por feitiçaria em Portugal, levantados por Pedro Paiva entre os anos de 1600 a 1774, numa amostragem de 690 processos

27. Carlo Ginzburg, Mitos, emblemas e sinais. Morfologia e história (São Paulo: Companhia das Letras, 1989) 178.

28. Souza, O diabo e a Terra de Santa Cruz 211.

29. Luiz Mott, "Quatro mandingueiros de Jacobina na Inquisição de Lisboa”, Afro-Ásia 16 (1995): $148-160$.

30. Souza, O diabo e a Terra de Santa Cruz 384. 
encontrados, $8 \%$ foram de portadores de bolsas de mandinga. ${ }^{31}$ Em levantamento que realizamos para os africanos e afrodescendentes residentes em Portugal, entre os séculos XVI e XVIII, encontramos, entre denúncias e processos, 30 casos, sobretudo entre 1701 e 1760, correspondendo a 32,3\% do total de casos relativos a outras práticas mágico-religiosas perpetradas por este grupo. Este total só perde para as práticas mágicas voltadas para os relacionamentos pessoais, tendência geral das estatísticas sobre feitiçaria em Portugal e Brasil. ${ }^{32}$

As bolsas podiam ser feitas de couro, veludo, chita ou seda, e podiam ser usadas penduradas ao pescoço, atadas aos braços, na cintura ou cruzadas no peito. Continham ingredientes bastante variados, combinados de diversas maneiras: ossos de defuntos, cabelos, raízes, sementes, sangue de animais, bebidas, como aguardente, pedras diversas, madeiras, pelos, penas, olho de gato, pólvora, balas de chumbo, desenhos de Cristo crucificado, hóstias, orações dedicadas a santos, com São Marcos, São Cipriano, dentre outros. A pedra d'ara — pedaço de mármore sobre o qual os sacerdotes durante as missas consagravam a hóstia e o vinho - também era bastante procurada como ingrediente, misturadas a orações e outros elementos. Em se tratando de um altar essencial para o ritual da Eucaristia, tinha grande significado, e pequenas partes dela eram utilizadas em várias ocasiões e de diversos modos. Já eram vistas em si mesmas como objeto de proteção, sendo também portadas isoladamente como amuletos. ${ }^{33}$

A força das mandingas estava relacionada, no mais das vezes, ao tratamento que deviam receber para terem seu poder de proteção ampliado. Em muitos processos e denúncias encontramos informações de que depois de preparadas, deviam ser defumadas com ervas e incensos, benzidas, e enterradas à meia-noite em encruzilhadas ou postas debaixo da pedra d'ara no altar de uma igreja para em cima delas serem rezadas três missas, adquirindo assim mais potência e eficácia. Os exemplos são vários na documentação inquisitorial portuguesa, demonstrando a grande necessidade de proteção através da bolsa de mandinga, embora o seu porte tivesse levado a muitos aos cárceres inquisitoriais.

Em alguns lugares, particularmente, o uso da bolsa era visto como indispensável. Em 1713, o forro Joseph de Pina, soldado auxiliar na vila de Mazagão, advertiu ao também forroVicente de Morais que ali era necessário muita cautela, correndo-se até risco de vida. Localizada no litoral atlântico marroquino, esta praça militar e comercial portuguesa, que teve no século XV sua fase áurea, ainda vivia rodeada de perigos pelo ir e vir de mercadores cristãos, mouros e judeus, e lá o intercâmbio das bolsas entre brancos e negros era intenso. ${ }^{34}$

31. Paiva 208.

32. Calainho 289.

33. Ver, por exemplo, ANTT, Lisboa, Inquisição de Lisboa, Processos 11774, 254, 724 e 16479 e Inquisição de Coimbra, Processo 1630.

34. ANTT, Lisboa, Inquisição de Lisboa, Processo 5477. 
João de S. Boaventura, religioso, dizia que "muita gente em Lisboa usava delas", denunciando ao Santo Ofício em 1700 um escravo da cidade de Sintra que trazia uma bolsa, cujo poder fora comprovado, segundo ele, numa ocasião em que foi ferido na garganta por uma adaga, "sem que esta lhe fizesse ferida ou sinal algum". Este denunciante fez alusão ainda a um decreto publicado pelo Santo Ofício, tratando especificamente da obrigatoriedade da denúncia dos portadores das bolsas e demonstrando que realmente era grande seu uso. ${ }^{35}$

O significado do uso das bolsas de mandinga era de tal monta, que se estruturou um intenso comércio que cruzou o Atlântico, visto à farta nos processos inquisitoriais que examinamos e que incriminaram seus portadores como feiticeiros. Em 1692, o escravo Diogo, de propriedade de Manoel Avelar Camado, foi denunciado por porte de uma bolsa que continha pedaços de pedras e sementes, tudo embrulhado num tecido de algodão. $\mathrm{O}$ denunciante, João Antunes, barbeiro, havia comprado deste cativo uma outra bolsa e sabia também de outros que haviam adquirido um. ${ }^{36}$

Mas um dos casos mais exemplares deste comércio foi o de Joseph Francisco Pereira, preso pela Inquisição de Lisboa em 1730. Nascido na Costa da Mina, foi traficado para o Brasil e serviu na cidade de Recife, ainda jovem, ficando por lá durante uns dez anos. Depois seguiu para o Rio de Janeiro, para Minas do Rio das Mortes e por fim para Lisboa, onde estava há quase dois anos à época de sua prisão. Seu último senhor era um Capitão-mor das Minas, nascido no Brasil, não havendo nenhuma informação no processo sobre seus outros senhores. No ir e vir de homens que circulavam com seus escravos, fazendo negócios e várias outras atividades, Joseph Francisco Pereira foi adquirindo conhecimentos ao longo dos caminhos que trilhou. Contou aos inquisidores que "nos Brasis" aprendeu muitas coisas, como cartas de tocar para atrair mulheres, andar com uma raiz de trigo para não o maltratarem, trazer consigo papéis com orações e confeccionar as bolsas de mandingas, ensinada por vários escravos em Pernambuco. Ainda no Brasil, começou a vendê-las, abrindo algumas que comprou no Rio de Janeiro e delas fazendo outras. Já em Lisboa, corria a fama entre os escravos e libertos que José Pereira vinha do Brasil, terra onde sabiam ser "frequente o uso de mandingas", sendo assim procurado por muitos que acreditavam que a aquisição da bolsa lhes possibilitaria condições melhores de vida, como serem libertados pelos senhores, terem mulheres, ganhar no jogo, se protegerem. ${ }^{37}$

Joseph Francisco Pereira era também auxiliado por Joseph Francisco Pedroso, em cujo processo muitos de seus clientes também estavam relacionados ao Brasil, fosse embarcando com seus senhores para a colônia, ou então sendo vendidos para lá. Confessou aos inquisidores que vários escravos eram seus clientes em Lisboa e que ainda indicava colegas que também as vendiam quando estava sobrecarregado.

35. ANTT, Lisboa, Inquisição de Lisboa, Correspondência recebida, Livro 292.

36. ANTT, Lisboa, Inquisição de Lisboa, Cadernos do Promotor 66, Livro 260.

37. Em vários processos os inquisidores já explicitavam que já tinha conhecimento do Brasil como local importante na rota das mandingas. ANTT, Lisboa, Inquisição de Lisboa, Processo 11767. 
Por vezes também comprava bolsas de outros, como de um escravo de um negociante que veio do Brasil, e era auxiliado por um criado branco que copiava orações e por outro escravo, chamado Ventura, que as colocava debaixo dos altares de igrejas para adquirirem mais força ${ }^{38}$ Este último também, voltando com seu senhor para o Rio de Janeiro em 1735, dera nesta cidade uma bolsa de mandinga ao escravo Antônio Mascarenhas em forma de carta com várias figuras pintadas, advertindo-o ainda que pusesse debaixo de uma pedra d'ara com o fito "de ser mais forte e segura". Quando retornou ao Funchal, na Ilha da Madeira, aonde chegou criança vindo de Angola, pediu ao estudante Antônio da Silva que transcrevesse aquilo tudo, provavelmente com o intuito de vender. ${ }^{39}$

Outro processo interessante para se perceber o circuito atlântico das mandingas foi do escravo Luiz de Lima, natural da Costa da Mina e morador no Porto. Em 1729 se apresentou à Inquisição, confessando ser vendedor de bolsas a partir de uma que havia trazido do Brasil. Feita de veludo verde, havia comprado do escravo Francisco em 1722, contendo um pedaço de pedra d'ara e uma oração de São Marcos e São Cipriano. Já em Portugal, dividiu o conteúdo dela e vendeu a Joseph da Costa, escravo de um sargento de Massarelos, no Bispado do Porto, e daí não parou mais. Em três anos mais ou menos, criou uma rede de mandingueiros a partir de vários contatos com escravos e forros moradores do Porto. Vendeu a vários cativos de senhores moradores no Brasil, como Domingos, Francisco, Nicolau - que sabia "muito de feitiçarias" — , e a um tal Joseph Luis, uma unha de onça de prata para ser usada também como amuleto protetor. Mas diante do Inquisidor, denunciou outros tantos escravos e forros, como Sebastião; Antônio Criança; Inácio; Antônio (cujo senhor também nascera no Brasil); Pedro, que estivera em Pernambuco; Francisco, depois vendido a um comerciante nascido no Brasil, e outros. Infelizmente não conseguimos localizar todos estes processos.

Luis de Lima denunciou ainda o escravo Purieiro, também usuário das mandingas no Brasil, e quando chegou a Portugal, ganhou fama por ser "grande mandingueiro", confeccionando-as e vendendo-as depois de bentas. Quando conheceu Luis de Lima, em Pernambuco, lhe vendeu "uma coisa feita por modo de esteira, e pequena, tecida de uma casta de pau tingido de preto, a qual coisa servia para adivinhar", mas "por entender que aquela coisa de adivinhar era muito proibida no Reino, não a trouxe". Recebeu ainda do escravo Damião, que veio do Brasil com seu senhor, uma bolsa que foi vendida depois para outro escravo. Por fim, Luis de Lima enunciou o escravo Félix, morador em Chaves, Portugal, outrora seu companheiro em Pernambuco, ambos propriedade de um Desembargador. Afirmou que o tal Félix conhecia outros "grandes mestres" no Recife, tendo presenciado numerosas brigas em que saíram incólumes. O destino deste escravo, completou, fora a venda para o Rio de Janeiro, bastante dificil, "por ser 
grande mandingueiro e por isto ser sabido e bem conhecido [...], ninguém o queria comprar". ${ }^{40}$

Nestes processos inquisitoriais, evidencia-se a dinâmica da mobilidade geográfica dos escravos em função do trânsito de funcionários do Reino, da burocracia colonial e dos comerciantes, que ficavam no trânsito entre Brasil e Portugal com seus cativos, permanecendo determinados períodos ora num, ora noutro lugar. ${ }^{41}$ Muitas vezes ainda compravam e vendiam escravos, incrementado mais ainda esta circulação. Além de tudo, o caráter da escravidão urbana em Portugal facilitava enormemente estas trocas culturais, pondo africanos escravizados e forros em contato permanente, cruzando-se nas ruas, em meio às suas tarefas quotidianas. ${ }^{42}$

Para a região das Minas, no Brasil, entre 1718 e 1738, existem alguns dados quantitativos que demonstram a presença destes africanos vindos do Reino, compondo $21,7 \%$ da população escrava nas localidades de Vila Rica,Vila do Carmo e Tejuco, conforme estudo de Renato Pinto Venâncio. Supõe-se que eram propriedade de portugueses abastados atuando na colônia, e até uma espécie de "reserva de valor" em função dos altos preços que obtinham no Brasil pela sua qualificação profissional adquirida em Portugal, sendo interessante portanto que viessem para serem alugados ou até mesmo vendidos. ${ }^{43}$ Observamos assim que em meio ao fluxo contínuo dos senhores entre Brasil e Portugal, seus escravos e mesmo negros forros partilhavam suas crenças e seus conhecimentos, que iriam circular pelos recantos do lado ocidental do Império português.

O estudo da circulação das bolsas de mandinga no espaço atlântico é, assim, exemplo das conexões pensadas por Russell-Wood, que enfatizam

[...] aspectos que ultrapassam/transcendem as fronteiras políticas ou nacionais; as conexões, interconectividade, redes e diásporas que ligam a Europa, as Américas e a África; intercâmbio, seja de indivíduos, de flora e fauna, de mercadorias e produtos, seja de línguas, de culturas, de manifestações de fé, e de costumes e práticas tradicionais; um Atlântico caracterizado pelo movimento, pelo vaivém, e transições, e a vários ritmos de aceleração; e um mundo onde instituições, mesmo reinos, se formam, reformulam-se de um modo distinto, fragmentam-se, apenas para reaparecerem com uma nova configuração. Um conceito inerente a esta história é que nenhuma parte possa existir em isolamento. Um evento - epidemia, seca, guerra, fome - em uma parte tem repercussões e ressoa em outras partes. ${ }^{44}$

40. ANTT, Lisboa, Inquisição de Coimbra, Processo 1630.

41. A.J. R. Russell-Wood, “Governantes e agentes”, História da expansão portuguesa, vol. 3, dirs. Francisco Bethencourt e Kirti Chaudhuri (Lisboa: Círculo de Leitores, 1998) 169-192.

42. A. C. de C. M. Saunders, História social dos escravos e libertos negros em Portugal (1441-1555) (Lisboa: Imprensa Nacional / Casa da Moeda, 1994).

43. Renato Pinto Venâncio, Cativos do Reino: a circulação de escravos entre Portugal e Brasil, séculos 18 e 19 (São Paulo: Alameda, 2012).

44. Russell-Wood, "Sulcando os mares" 20-21. 
O uso das bolsas de mandingas por homens brancos em Portugal e ainda no Brasil sugere também outro aspecto desta circularidade, em se tratando do fato de que seu uso era uma prática majoritariamente vinculada aos africanos e seus descendentes, como no caso dos calundus. Em vários processos estão homens brancos pedindo bolsas aos africanos, comprando-as deles e até vendendo-as aos próprios. Jacques Viegas, o escravo que nos legou, sem querer, uma de suas bolsas, tomada pelos Inquisidores quando foi preso em 1704 e esquecida em meio ao seu processo, recebeu em sua casa vários brancos interessados nas mandingas. A um deles, deu uma, contendo "um bocadinho de lã com um vintém de almíscar, tudo cozido num paninho roxo", em troca de uma faca e uma garrafa de vinho. ${ }^{45}$

A própria estrutura de repressão do Santo Ofício colaborou para muitos contatos e intercâmbios desses saberes. De todas as penas imputadas aos réus considerados como feiticeiros, $80 \%$ foram de degredo associado a prisões e açoites. No século XVII, o Brasil foi região para onde o Santo Ofício mais despachou seus réus, e no XVIII, o próprio Reino e as ilhas atlânticas foram os locais privilegiados, além da própria África, particularmente Angola. ${ }^{46}$ Propagaram-se assim, por esta via, muitos dos valores culturais e religiosos africanos, ou quem sabe, afrobrasileiros, mas também outras condutas heterodoxas. ${ }^{47}$ Penitenciados pelo Santo Tribunal, estes indivíduos acabavam por reproduzir, nos locais onde cumpriam o desterro, as mesmas práticas através das quais haviam sido condenados, não tendo como subsistir a não ser reiniciando suas "artes", cobrando por seus serviços, criando nova fama no lugar e até ensinando a outros. Foi o caso de muitos curandeiros e mandingueiros, que as fontes inquisitoriais são fartas a descrever. Laura de Mello e Souza, estudando casos de feiticeiras portuguesas degredadas para o Brasil, comprovou tanto permanências quanto alterações de práticas que foram se disseminando também por esta via pelo Império português. Diria ela que

Mecanismo punitivo corrente do Antigo Regime, o degredo serviu para garantir a perpetuação de formas culturais portuguesas (europeias) no seio da sociedade colonial. Algumas se cristalizaram e permaneceram inalteradas através dos tempos. Mas muitas se recombinaram e se refundiram em modalidades especificamente coloniais de feitiçaria, magia e religiosidade popular. ${ }^{48}$

45. ANTT, Lisboa, Inquisição de Lisboa, Processo 2355.

46. Paiva 218.

47. Thaís Tanure de Oliveira Costa, em dissertação de mestrado sobre degredados africanos, fez um balanço geral de escravos e forros que receberam esta pena entre os séculos XVI e XVIII. Mesmo com uma amostragem pequena, mapeou os destinos destes indivíduos e analisou as relações que envolveram senhores e escravos mediante esta punição inquisitorial.Ver Thaís Tanure de Oliveira Costa, "'Nas terras remotas o diabo anda solto': Degredo, Inquisição e escravidão no mundo atlântico português (séculos XVI a XVIII)" (Dissertação de mestrado em História, Universidade Federal de Minas Gerais, 2018).

48. Laura de Mello e Souza, Inferno atlântico. Demonologia e colonização. Séculos XVI-XVIII (São Paulo: Companhia das Letras, 1993) 101. 
Também em relação aos casos que estudamos, o degredo, associado a açoites, foi pena que mais se imputou aos africanos e afrodescendentes em Portugal, punidos por feitiçaria, fazendo circular, nos casos das bolsas de mandinga, esta prática considerada herética pela Inquisição portuguesa. ${ }^{49}$

\section{Mandingas luso-afro-brasileiras}

O porte de amuletos protetores era comum em muitas comunidades da África Ocidental e Central. O termo "mandinga", associado ao porte de amuletos, relaciona-se, no entanto, a uma parcela da história dos muçulmanos na África. Desde o século VII, a expansão árabe começou a penetrar no norte deste continente, configurando ao longo do tempo um comércio relativamente estruturado, com importantíssimas rotas terrestres e intensa troca de produtos pelas caravanas de mercadores. Mas foi só no século XI que o islamismo penetrou na chamada África negra, para além do rio Níger, com o avanço da tribo Sanhadja, fundadores do califado árabe almorávida, saindo dos limites do Marrocos e do Senegal. O século XIII vai assistir à conversão ao islamismo do reino Mali, cujos habitantes, os malinkê, eram também conhecidos por mandingas. Localizavam-se no vale do Níger, na Costa da Guiné, desbravada pelos portugueses em 1444 e onde se configurou neste período duas grandes áreas de exportação de cativos, o Castelo de São Jorge e o Benin. ${ }^{50}$

Nesse grupo dos mandingas o uso de patuás protetores era característico, feitos em forma de bolsas de couro e contendo orações e passagens do Alcorão, como bem observou o Padre Manoel Álvares, da Companhia de Jesus, estando de passagem pela Guiné em 1607:

Há nestas partes certa gentilidade a que chamam Mandingas, que é a pior gente, porque guardam a seita dos mouros e confinam com eles nos costumes e nas terras com os Jalofos. Estes andam metidos com esta gentilidade e os enganam, dando-lhes nominas e uns relicários que trazem ao pescoço, assim como os agnus Dei e outras relíquias. São estas nominas uns pedaços de couros cozidos de diversos modos e neles trazem o que estes mouros lhe dão e semeam a cizânea de sua perversa seita. ${ }^{51}$

Era comum o uso destes talismãs na Costa da Guiné, não apenas sob a forma de bolsas, mas também como objetos avulsos supostamente dotados de grande força e poder, daí a necessidade do contato físico do objeto com o corpo do usuário, sendo usado pendurado ao pescoço ou junto às roupas. ${ }^{52} \mathrm{O}$ espectro da proteção

49. Calainho, Anexo I, Tabela 14.

50. Joseph Ki-Zerbo, História da África negra (Lisboa: Publicações Europa-América, 1972) 129-180; Ver também J. D. Fage, História da África (Lisboa: Edições 70, 1995); Elikia M’Bokolo, África negra. História e civilizaçooes, t. I (Salvador / São Paulo: EDUFBA / Casa das Áfricas, 2009).

51. "Relação das coisas da Guiné (Maio-1607)", Monumenta missionaria africana, segunda série, vol. IV, comp. António Brásio (Lisboa:Agência Geral do Ultramar, 1968) 274.

52. Hubert Deschamps, Las religiones del África negra (Buenos Aires: Editorial Universitaria de Buenos Aires, 1962) 62. 
era amplo, abrangendo as ameaças quotidianas, conflitos, doenças, maus espíritos, sendo usados, por comerciantes, guerreiros e pessoas comuns. Confeccionados por "mestres" espirituais letrados, estes amuletos recebiam seus poderes místicos e eram fonte significativa de renda para muitos por sua larga comercialização em várias regiões da África. ${ }^{53}$ Concentradores da força mágica, numa conexão direta com quem os portava, agia em todos os planos representando uma segurança em relação à vida e também em relação à morte..$^{54}$

Thiago Mota, em doutoramento recente, fez interessantes considerações relacionadas à chegada e incorporação da religião islâmica na Senegâmbia, articulando-se às culturas religiosas locais por intermédio dos amuletos, que se ressignificaram com o islamismo. Ressalta que as bolsas de mandinga não tinham um significado por si próprias, e sim relacionadas ao contexto histórico e social em que estavam inseridas. Não considera que a islamização na África se constitua por uma mera substituição de práticas religiosas, e sim esteja relacionada a um processo contínuo de trocas culturais articulados pelos agentes históricos que ressignificam estas práticas ao longo do tempo, sendo as bolsas um exemplo neste sentido:

os amuletos da Senegâmbia, chamados pelos missionários de bolsas de mandinga, foram elementos que facilitaram comunicações interculturais, atuando no estabelecimento de relações entre o Islã e as culturas religiosas locais. Em torno dos diálogos referentes aos sentidos e usos da peça, foi possível à religião islâmica fazer seu aparecimento nos confins da Serra Leoa, numa linguagem acessível a povos cuja experiência religiosa organizava-se a partir do relacionamento com o mundo espiritual mediado pela cultura material. ${ }^{55}$

Em meados do século XVI, com o início do contato dos povos mandingas com os portugueses e o crescimento do comércio na costa, vários relatos de viajantes, missionários e mercadores acabaram por associar os mandingas a feiticeiros. $\mathrm{O}$ comerciante André Donelha, por exemplo, em sua passagem pela Costa da Guiné, em 1624, ressaltou não apenas o caráter muçulmano dos mandingas, através dos chamados bixiriis, sacerdotes islâmicos, como ainda o uso dos patuás: "o que levam para vender são feitiços em cornos de carneiros e nóminas e papéis escritos, que vendem por relíquias, e com vender tudo isso semeiam a seita de Mafamede por muitas partes, e vão em romaria à casa de Meca e correm todo o sertão d'Etiópia". ${ }^{6}$

A origem étnico-cultural dos africanos portadores das bolsas de mandinga no mundo luso-brasileiro nos remete a uma outra dimensão desta circulação cultural.

53. J. Spencer Trimingham, A History of Islam in West Africa (London: Oxford University Press, 1970); apud João José Reis, Rebelião escrava no Brasil. A história do levante dos malês, 1835 (São Paulo: Brasiliense, 1986) 123.

54. Jean Chevalier e Alain Gheerbrant, Dicionário de símbolos. Mitos, sonhos, costumes, gestos, formas, figuras, cores, números (Rio de Janeiro: José Olympio, 1998) 49.

55. Thiago Henrique Mota, "História Atlântica da islamização na África Ocidental. Senegâmbia, séculos XVI e XVII" (Tese de doutorado em História, Universidade Federal de Minas Gerais, 2018) 201.

56. André Donelha, Descrição da Serra Leoa e dos Rios de Guiné do Cabo Verde (1625), apud Mota 201. 
Embora os mandinga fossem um dos povos guineenses, e apesar de que alguns portadores das mandingas tivessem esta origem, o fato é que outros grupos foram também usuários. $\mathrm{Na}$ amostragem sobre os africanos denunciados e processados por uso destas bolsas em Portugal entre os séculos XVI e XVIII, temos nove originários da Costa da Mina, dois do Congo e cinco de Angola, num total de dezenove casos. ${ }^{57}$ Levantamos as informações sobre as origens étnicas desses indivíduos nas sessões de inquirição, e mesmo no caso dos recém-chegados que ainda não falavam o português, os inquisidores utilizavam intérpretes. No caso das denúncias, no entanto, a informação da origem do denunciado nem sempre aparecia. Esta prática no mundo luso-brasileiro não espelhou, portanto, uma homogeneidade étnica de determinado grupo, e sim envolveu outros, fruto do processo de desarticulação cultural, social e religiosa que se estabeleceu a partir do tráfico, havendo assim um rearranjo de novas formas de sociabilidade e religiosidade.

Vanicléia Silva, em sua tese de doutorado, fez importante estudo sobre vários portadores destes patuás no sertão da Bahia setecentista, confirmando o circuito atlântico que marcou esta prática. Também constatou que as origens de seus usuários não tinham uma relação direta com os povos mandingas da Alta Guiné, e foi além, correlacionando detalhadamente as dinâmicas políticas envolvendo o Reino de Mali e outros povos, relacionadas à história do tráfico atlântico na região. Enfatizou, ainda, a generalização do uso do termo "mandinga" e "mandingueiro" para designar algumas das práticas mágico-religiosas que circulavam pelo Atlântico, mediante à imagem dos povos mandingas como feiticeiros, baseada em farta documentação. ${ }^{58}$

Mas acrescentaríamos a esta discussão o fato de que em muitos dos processos e denúncias que consultamos, os inquisidores associaram as "mandingas" — no caso, as bolsas - ao Brasil, preocupados, sempre, com a difusão e a origem das práticas heréticas, sendo constantes certas indagações, como o local onde aprendeu este ou aquele feitiço ou oração, e se ensinou a mais alguém e quem foi; se induziu a outra pessoa a firmar pacto com o Diabo; quantos e quem foram curados; de onde vieram as mandingas e quem eram seus usuários, no Brasil e em Portugal. A postura do Tribunal era deter os avanços destas práticas e tentar dominar o espaço onde poderiam atuar, e os exemplos nos processos são vários. No caso das bolsas, o discurso inquisitorial foi ímpar em imputar à colônia uma prática que na verdade não era originária nem típica deste espaço, muito pelo contrário. A abrangência da diáspora africana mesclou culturas, crenças e povos distintos, ensejando complexas situações onde ritos religiosos e costumes imiscuíram-se de diferentes maneiras, envolvendo etnias diversas.

Nina Rodrigues e Arthur Ramos, a propósito da Revolta dos Malês na Bahia de 1835 , foram os pioneiros no Brasil nos estudos sobre os amuletos islamizados

57. Calainho, Anexo I, Tabela 10.

58. Vanicléia Silva Santos, “As bolsas de mandinga no espaço Atlântico. Século XVIII” (Tese de doutorado em História, Universidade de São Paulo, 2008). 
de origem africana. ${ }^{59}$ Estes patuás ganharam novo destaque várias décadas depois com o estudo de João Reis, sobre o mesmo conflito, pois este autor demonstrou como a versão islamizada das bolsas de mandinga portadas pelos malês neste período foi também exemplo notável do processo de reconstrução da identidade étnica dos africanos e da circularidade de saberes e de certas práticas religiosas e culturais. ${ }^{60}$ Os primeiros africanos islamizados aportaram no Brasil entre fins do XVIII e inícios do XIX, principalmente os grupos haussá, iorubás, jejês e outros, impulsionados pela expansão do islã em certas regiões da África Ocidental, que produziu milhares de escravos. ${ }^{61}$

No entanto, estes amuletos protetores do século XIX tinham uma natureza totalmente distinta daqueles encontrados nos séculos XVII e XVIII na colônia. Em nenhum dos processos ou denúncias que localizamos em Portugal e no Brasil, relativos ao porte destas bolsas, houve menção ou referências a rezas islâmicas ou outros indícios de islamismo, e sim elementos do cristianismo junto a outros ingredientes, fossem dentro das bolsas - como hóstias, orações, pedras d'ara, por exemplo - ou envolvendo-as de alguma maneira, como colocá-las debaixo de um altar onde seriam rezadas missas objetivando ganharem mais força protetora. John Thornton foi preciso quando chama atenção para o contato dos africanos, na própria África, com o cristianismo, facilitando as relações no Novo Mundo e suas interações no mundo atlântico. Junto com Wyatt MacGaffey, demonstrou, estudando o reino do Congo, como que lá a aceitação e absorção da religião católica foi possível por conta de correlações com as próprias tradições bantas. ${ }^{62}$ Portanto, seja através dos africanos vindos do Congo e Angola,já cristianizados pela presença importante dos portugueses pela região, ou mesmo pelo processo de evangelização

59. Nina Rodrigues, Os africanos no Brasil (São Paulo: Companhia Editora Nacional, 1976); Arthur Ramos, O negro brasileiro, vol. 1 (São Paulo: Companhia Editora Nacional, 1940).

60. “Em 1820-35, os nagôs, jejes, haussás e tapas constituíram 57,3\% dos escravos africanos [...] Uma vez na Bahia, esses escravos iriam modificar fundamentalmente a vida da comunidade africana que aí vivia, tanto em termos de sua estrutura interna - hierarquias sócio-culturais, estratégias de alianças e conflito interétnico, reorganização do espaço urbano de trabalho, etc. — como em termos de seu relacionamento com a classe senhorial e os habitantes nativos de um modo geral. Foi nesse período que a cultura jeje-nagô se lançou no ambiente baiano com a força que a tornaria cultura africana dominante". Reis 170.

61. Muitos dos que vieram tinham, na África, posições de liderança religiosa e também guerreira, como os iorubás, que em meio à desagregação do império Oyo em inícios do XIX, formaram vários grupos armados independentes hostis entre si. Reis 171.

62. Usando a expressão de Wyatt MacGaffey, o "diálogo de surdos”, que se estabeleceu entre congoleses e portugueses representou a interpretação de mitologias de parte a parte, de acordo respectivamente com seu sistema de crenças, sem conflitos aparentes. Neste sentido, por exemplo, os objetos utilizados nos rituais cristãos e nos rituais congoleses, recebiam a mesma designação (nkisi), como também os padres portugueses e mágicos locais, executores das mesmas funções. Wyatt MacGaffey, "Dialogues of the deaf: Europeans on the Atlantic Coast of Africa", Implicit Understandings: Observing, Reporting, and Reflecting on the Encounters between Europeans and Other Peoples in the Early Modern Era, ed. Stuart B. Schwartz (Cambridge: Cambridge University Press, 1994) 260. 
no Novo Mundo, o fato é que elementos do cristianismo estiveram presente nas bolsas. $^{63}$

O já citado forro Vicente de Morais, em 1716, apegava-se à sua bolsa de mandinga, que continha orações em latim, "um bocado de agnus dei e uma coisa verde que ele não conheceu", confessou ao inquisidor. ${ }^{64}$ Os escravos do sertão da Bahia setecentista, na vila de Jacobina, estudados por Luiz Mott, e posteriormente por Vanicléia Santos, foram também exemplo desta mescla de crenças. Em 1745, o vigário da freguesia instaurou um sumário de culpas acusando quatro escravos suspeitos de portarem bolsas contendo orações a santos, hóstias, pedaços da pedra d'ara e do círio pascal. Passaram mais de 10 anos nos cárceres inquisitoriais, sofreram torturas, vivenciaram o terremoto de 1755, mas saindo ilesos do prédio destruído da Inquisição em Lisboa.Voltaram para a prisão depois de reconstruída, confessaram pacto demoníaco e foram por fim degredados por curto período para outras regiões de Portugal. ${ }^{65}$

O já citado mandingueiro José Francisco Pereira, um dos mais famosos e estudados do circuito atlântico, preso em 1745, em cuja bolsa continham vários desenhos que ilustravam orações, ganhou estudo inovador por parte de Vanicléia Santos, interpretando as imagens como fruto do aprendizado do cristianismo mesclado às crenças bacongas. Didier Lahon, também correlacionando os elementos gráficos deste processo, associou a tradições voduns do reino de Daomé — de onde procedia este mandingueiro — alguns elementos africanos, mas sobretudo cristãos. ${ }^{66}$

\section{Conclusão}

Para concluir, consideramos fundamental a discussão sobre o "grau de continuidade ou de mudanças sofrido pelas culturas religiosas de origem africana no Novo Mundo", nas palavras de Luis Nicolau Parés, que contribuiu enormemente para a reflexão sobre as identidades étnicas relacionadas a certas crenças e práticas religiosas ao estudar as influências da nação jeje no candomblé na Bahia, considerando certas tradições da Costa da Mina, em especial os cultos de vodum, como fundamentais para a institucionalização deste ritual. ${ }^{67}$ Ainda que considere este aspecto

63. John Thornton, A África e os africanos na formação do mundo atlântico, 1400-1800 (Rio de Janeiro: Elsevier, 2004);Ver também John Thornton, "The Development of an African Catholic Church in the Kingdom of Kongo, 1491-1750", The Journal of African History 25.2 (1984): 147-167.

64. ANTT, Lisboa, Inquisição de Lisboa, Processo 5477.

65. Mott, "Quatro mandingueiros".

66. Didier Lahon, "Esclavage et Confréries noires au Portugal durant l'Ancien Régime (14411830)" (Tese de doutorado em Antropologia Social e História, École des Hautes Études en Sciences Sociales, 2001).

67. Luis Nicolau Parés, A Formação do Candomblé: história e ritual da nação jeje na Bahia (Campinas: Editora da Unicamp, 2006) 16. 
de "continuidade", enfatiza o caráter múltiplo do candomblé, não se tratando de "unidades estanques, homogêneas e mutuamente exclusivas". ${ }^{6}$

Refletir sobre a religiosidade dos africanos e afrodescendentes no mundo atlântico a partir do exemplo das bolsas de mandingas, é perceber um universo multifacetado, sujeito a influências cristãs, muçulmanas e de seus cultos de origem, coexistindo aspectos europeus e também africanos. Este universo de crenças acabou por assumir um perfil híbrido, seguindo a perspectiva de análise de Carlo Ginzburg, ${ }^{69}$ diferentemente de Melville Merkovitz e Roger Bastide, que direcionaram seus trabalhos para uma vertente em que reafirmaram a continuidade das formas culturais africanas. ${ }^{70}$ Também James Sweet ressaltou os traços africanos encontrados na bolsas de mandinga, vendo-as como arma de luta contra a escravidão na diáspora. ${ }^{71}$

Já autores como Richard Price e Sidney Mintz destacam o que chamaram de "crioulização" da religiosidade afro-brasileira, entendendo-a no contexto da especificidade socio-cultural brasileira, e não enfatizando as suas origens africanas:

As formas sociais e culturais afro-americanas foram forjadas na fogueiras da escravidão, mas não podiam nem podem ser definidas em se as restringindo aos povos ou sociedades cujas origens físicas eram africanas, do mesmo modo que as formas sociais e culturais euro-americanas não podem ser limitadas àqueles cujas origens fisicas eram europeias. ${ }^{72}$

Esta crítica à busca pelos africanismos não nega, evidentemente, a presença africana em rituais e crenças, porém enfatiza as modificações que dentro do contexto colonial ou mesmo europeu transformam tais ritos e crenças, acabando por adquirir uma personalidade própria. As mandingas representaram uma das várias maneiras através das quais os africanos buscaram reconstruir sua identidade, criar laços sociais e se reorganizar fora da África, incorporando aos resquícios de seu passado cultural e religioso elementos da cultura europeia. $\mathrm{Na}$ verdade, consideramos que mais importante do que rastrear sua origem, é perceber seus significados nos contextos sociais em que acabaram por se inserir.

Circulando no espaço atlântico pelas mãos dos africanos escravizados, forros e até mesmo de brancos, o porte destes amuletos protetores - as bolsas de mandinga — foi um tipo de prática que se reelaborou no espaço e no tempo e ainda se difundiu para outros grupos. Demonizada pela Inquisição e considerada como feitiçaria, se "mundializou", para usar uma expressão de Serge Gruzinski, ao mesmo tempo em que a Igreja católica lutava, incansável, numa cruzada contra o paganismo e as crenças heréticas na América, na África e na Ásia em prol da ortodoxia católica.

68. Parés 102.

69. Carlo Ginzburg, História noturna. Decifrando o sabá (São Paulo: Companhia das Letras, 1991) 22.

70. Roger Bastide, As Américas negras: as civilizações africanas no Novo Mundo (São Paulo: Difel, 1974); Roger Bastide, As religiões africanas no Brasil (São Paulo: Livraria Pioneira Editora, 1989).

71. Sweet.

72. Sidney W. Mintz e Richard Price, O Nascimento da cultura afro-americana: uma perspectiva antropológica (Rio de Janeiro: Pallas / Universidade Candido Mendes, 2003) 112 


\section{Fontes}

\section{Manuscritas}

Arquivo Nacional da Torre do Tombo, Lisboa (ANTT)

Inquisição de Lisboa

Inquisição de Coimbra

\section{Impressas}

Brásio, António. Comp. Monumenta missionaria africana. Segunda série. Vol. IV. Lisboa: Agência Geral do Ultramar, 1968.

\section{Internet}

www.slavevoyages.org

\section{Bibliografia}

Bastide, Roger. As Américas negras: as civilizações africanas no Novo Mundo. São Paulo: Difel, 1974. . As religiões africanas no Brasil. São Paulo: Livraria Pioneira Editora, 1989.

Bailyn, Bernard. Atlantic History: Concepts and Contours. Cambridge: Harvard University Press, 2005.

."The Idea of Atlantic History". Itinerario 20.1 (1996): 19-44.

Bethencourt, Francisco e Kirti Chaudhuri. Dirs. História da expansão portuguesa. Vols. 1-3. Lisboa: Círculo de Leitores, 1998.

Bethencourt, Francisco. História das Inquisições: Portugal, Espanha e Itália, séculos XVXIX. São Paulo: Companhia das Letras, 2000.

- O imaginário da magia: feiticeiras, saludadores e nigromantes no século XVI. Lisboa: Centro de Estudos de História e Cultura Portuguesa, 1987.

Braudel, Fernand. O Mediterrâneo e o mundo mediterrânico na época de Filipe II. Lisboa: Publicações Dom Quixote, 1983.

. O Espaço e a História no Mediterrâneo. São Paulo: Martins Fontes, 1988.

Boxer, Charles R. O Império Marítimo Português, 1415-1825. São Paulo: Companhia das Letras, 2002.

. Salvador de Sá e a luta pelo Brasil e Angola, 1602-1686. São Paulo: Editora Nacional / Editora da Universidade de São Paulo, 1973.

Calainho, Daniela Buono. Metrópole das mandingas: religiosidade negra e Inquisição portuguesa no Antigo Regime. Rio de Janeiro: Garamond, 2008.

Chaunu, Pierre. Séville et l'Atlantique (1504-1650). Paris: Éditions de l'Institut des Hautes Études de l'Amérique Latine, 1959. 
Chevalier, Jean e Alain Gheerbrant. Dicionário de símbolos. Mitos, sonhos, costumes, gestos, formas, figuras, cores, números. Rio de Janeiro: José Olympio, 1998.

Costa,Thaís Tanure de Oliveira. “Nas terras remotas o diabo anda solto': Degredo, Inquisição e escravidão no mundo atlântico português (séculos XVI a XVIII)". Dissertação de mestrado em História, Universidade Federal de Minas Gerais, 2018.

Curtin, Philip D. The Atlantic Slave Trade: A Census. Madison: University of Wisconsin Press, 1969.

. The Tropical Atlantic in the Age of Slave Trade. Washington:American Historical Association, 1991.

Deschamps, Hubert. Las religiones del África negra. Buenos Aires: Editorial Universitaria de Buenos Aires, 1962.

Elliot, John. Do the Americas Have a Common History? An Address. Providence: John Carter Brown University, 1998.

Fage, J. D. História da África. Lisboa: Edições 70, 1995.

Ginzburg, Carlo. Mitos, emblemas e sinais. Morfologia e história. São Paulo: Companhia das Letras, 1989.

História noturna. Decifrando o sabá. São Paulo: Companhia das Letras, 1991.

Godechot, Jacques. Histoire de l'Atlantique. Paris: Bordas, 1947.

Greene, Jack P. e Philip D. Morgan. Atlantic History: a critical appraisal. New York: Oxford University Press, 2009.

Gruzinski, Serge. As quatro partes do mundo. História de uma mundialização. Belo Horizonte / São Paulo: Editora UFMG / Edusp, 2014.

Ki-Zerbo, Joseph. História da África negra. Lisboa: Publicações Europa-América, 1972.

Lahon, Didier. "Esclavage et Confréries noires au Portugal durant l'Ancien Régime (1441-1830)". Tese de doutorado em Antropologia Social e História, École des Hautes Études en Sciences Sociales, 2001.

MacGaffey, Wyatt. "Dialogues of the deaf: Europeans on the Atlantic Coast of Africa". Implicit Understandings: Observing, Reporting, and Reflecting on the Encounters between Europeans and Other Peoples in the Early Modern Era. Ed. Stuart B. Schwartz. Cambridge: Cambridge University Press, 1994.

Marcocci, Giuseppe e José Pedro Paiva. História da Inquisição Portuguesa, 15361821. Lisboa: A Esfera dos Livros, 2013.

Marcussi, Alexandre A. "Utopias centro-africanas: ressignificações da ancestralidade nos calundus da América portuguesa nos séculos XVII e XVIII". Revista Brasileira de História 39.79 (2018): 19-40.

Mauro, Frédéric. Le Portugal et l'Atlantique au XVIIe siècle, 1570-1670. Paris: École Pratique des Hautes Études, 1960.

M'Bokolo, Elikia. África negra. História e civilizações. Tomo I. Salvador / São Paulo: EDUFBA / Casa das Áfricas, 2009.

Mintz, Sidney W. e Richard Price. O Nascimento da cultura afro-americana: uma perspectiva antropológica. Rio de Janeiro: Pallas / Universidade Candido Mendes, 2003. 
Mott, Luiz. “O calundu angola de Luzia Pinta: Sabará, 1739”. Revista do Instituto de Arte e Cultura 1 (1994): 73-82.

. "Quatro mandingueiros de Jacobina na Inquisição de Lisboa”. Afro-Ásia 16 (1995): 148-160.

Mota, Thiago Henrique. "História Atlântica da islamização na África Ocidental. Senegâmbia, séculos XVI e XVII”. Tese de doutorado em História, Universidade Federal de Minas Gerais, 2018.

Paiva, José Pedro. Bruxaria e superstição num país sem "caça às bruxas" (1600-1774). Lisboa: Editorial Notícias, 1997.

Parés, Luis Nicolau. A Formação do Candomblé: história e ritual da nação jeje na Bahia. Campinas: Editora da Unicamp, 2006.

Ramos, Arthur. O negro brasileiro.Vol. 1. São Paulo: Companhia Editora Nacional, 1940.

Reis, João José. Rebelião escrava no Brasil. A história do levante dos malês, 1835. São Paulo: Brasiliense, 1986.

Rodrigues, Nina. Os africanos no Brasil. São Paulo: Companhia Editora Nacional, 1976.

Russell-Wood, A. J. R. "Governantes e agentes". História da expansão portuguesa. Vol. 3. Dirs. Francisco Bethencourt e Kirti Chaudhuri. Lisboa: Círculo de Leitores, 1998.

- Um mundo em movimento: os portugueses na África, Ásia e América (14151808). Algés: Difel, 1998.

. "Sulcando os mares: um historiador do império português enfrenta a 'Atlantic History"'. História 28.1 (2009): 17-70.

Santos,Vanicléia Silva. “As bolsas de mandinga no espaço Atlântico: Século XVIII”. Tese de doutorado em História, Universidade de São Paulo, 2008.

Saunders, A. C de C. M. História social dos escravos e libertos negros em Portugal (14411555). Lisboa: Imprensa Nacional / Casa da Moeda, 1994.

Souza, Laura de Mello e. O diabo e a Terra de Santa Cruz: feitiçaria e religiosidade popular no Brasil colonial. São Paulo: Companhia das Letras, 1986.

. Inferno atlântico. Demonologia e colonização. Séculos XVI-XVIII. São Paulo: Companhia das Letras, 1993.

. "Revisitando o calundu". Ensaios sobre a intolerância: Inquisição, Marranismo e Anti-Semitismo. Orgs. Lina Gorenstein e Maria Luzia Tucci Carneiro. São Paulo: Associação Editorial Humanitas, 2002.

Subrahmanyam, Sanjay. O Império asiático português 1500-1700. Uma História política e econômica. Linda-a-Velha: Difel, 1995.

Sweet, James H. Recriar a África: cultura, parentesco e religião no mundo afro-português (1441-1770). Lisboa: Edições 70, 2007.

Thomas, Keith. Religião e o declínio da magia: crenças populares na Inglaterra, séculos XVI e XVII. São Paulo: Companhia das Letras, 1991.

Thomaz, Luís Filipe F. R. De Ceuta a Timor. Lisboa: Difel, 1994. 
Thornton, John. A África e os africanos na formação do mundo atlântico, 1400-1800. Rio de Janeiro: Elsevier, 2004.

. "The Development of an African Catholic Church in the Kingdom of Kongo, 1491-1750". The Journal of African History 25.2 (1984): 147-167.

Trimingham, J. Spencer. A History of Islam in West Africa. London: Oxford University Press, 1970.

Venâncio, Renato Pinto. Cativos do Reino: a circulação de escravos entre Portugal e Brasil, séculos 18 e 19. São Paulo: Alameda, 2012. 